\title{
Ensiling of elephant grass with soybean hulls or rice bran ${ }^{1}$
}

\section{Ensilagem de capim elefante acrescida de casca de soja ou farelo de arroz}

\author{
India Joelma Gatass Monteiro²; Joadil Gonçalves de Abreu3; Luciano da Silva \\ $\mathrm{Cabral}^{3}$; Roberto Giolo de Almeida ${ }^{4}$; Rafael Henrique Pereira dos Reis \\ Arthur Behling $\mathrm{Neto}^{3 *}$; Carlos Eduardo Avelino Cabral ${ }^{3}$; Livia Vieira de Barros $^{3}$; \\ Anne Caroline Dallabrida Avelino ${ }^{6}$; Sarah Penso ${ }^{7}$
}

\begin{abstract}
The goal was to evaluate the chemical composition and fermentation pattern of elephant grass (Pennisetum purpureum Schum. cv. Roxo) silage with different levels of soybean hulls or rice bran. Two trials were conducted, comprising of a completely randomized design, with four replicates each. Treatments consisted on the addition of $0 \%, 5 \%, 10 \%$, and $15 \%$ of soybean hulls or rice bran to unwilted green elephant grass forage. Large PVC silos were used adopting a density of $600 \mathrm{~kg}$ of green mass $\mathrm{m}^{-3}$. The silos were opened 40 days after ensiling. The results revealed that the inclusion of $10 \%$ soybean hulls increased elephant grass forage dry matter (DM) content to $31 \%$, but did not alter the water soluble carbohydrate (WSC) content or buffering capacity. The resultant silages exhibited good fermentation patterns in terms of $\mathrm{pH}$ (less than 3.97) and $\mathrm{NH}_{3}-\mathrm{N}(4.07 \%$ total $\mathrm{N})$ levels. The inclusion of rice bran increased both DM and WSC content in the forage, improving the fermentation pattern of silages $(\mathrm{P}<$ 0.05 ). This too was verified by a $\mathrm{pH}$ lower than 3.92 and a maximum $\mathrm{NH}_{3}-\mathrm{N}$ of $4.23 \%$ of the total $\mathrm{N}$. The inclusion of $10 \%$ rice bran to the elephant grass improved the nutritional value of the forage to be ensiled and, hence, of the produced silage.
\end{abstract}

Key words: Additive. Ammonia nitrogen. pH. Pennisetum purpureum. Silage. Water soluble carbohydrates.

\section{Resumo}

Objetivou-se avaliar a composição bromatológica e o padrão de fermentação da silagem de capimelefante (Pennisetum purpureum Schum. cv. Roxo) aditivada com níveis de casca de soja e de farelo de arroz. Foram realizados dois experimentos para avaliar o uso de aditivos na ensilagem de capim elefante. Utilizou-se delineamento experimental inteiramente casualizado, com quatro repetições. Os tratamentos consistiram na adição de $0,5,10$ e $15 \%$ do aditivo na massa verde de forragem de capim-elefante picada e sem emurchecimento. Foi utilizado silos de PVC, adotando densidade de 600 $\mathrm{kg}$ de massa verde $\mathrm{m}^{-3}$, com abertura do silo 40 dias após a ensilagem. A inclusão de $10 \%$ de casca de soja aumentou o teor de matéria seca (MS) da forragem de capim-elefante para $31 \%$, porém não

\footnotetext{
${ }^{1}$ Parte da dissertação de mestrado do primeiro autor, apresentada ao Programa de Pós-Graduação em Ciência Animal, Universidade Federal de Mato Grosso, UFMT, Cuiabá, MT, Brasil.

2 M.e em Ciência Animal, UFMT, Cuiabá, MT, Brasil. E-mail: india.gattass@gmail.com

${ }^{3}$ Profs. Drs., Universidade Federal de Mato Grosso, UFMT, Cuiabá, MT, Brasil. E-mail: joadil@terra.com.br; lucianoufmt@ gmail.com; arthur_behling@hotmail.com; carlos.eduardocabral@hotmail.com; liviavieiradebarros@gmail.com

${ }^{4}$ Pesquisador, Empresa Brasileira de Pesquisa Agropecuária, EMBRAPA Gado de Corte, Campo Grande, MS, Brasil. E-mail: roberto.giolo@embrapa.br

5 Prof. Dr., Instituto Federal de Rondônia, IFRO, Colorado do Oeste, RO, Brasil. E-mail: rafael.reis@ifro.edu.br

${ }^{6}$ M.e em Agricultura Tropical, UFMT, Cuiabá, MT, Brasil. E-mail: annedallabrida@hotmail.com

${ }^{7}$ Discente do Curso de Doutorado em Ciência Animal, UFMT, Cuiabá, MT, Brasil. E-mail: spenso@gmail.com

* Author for correspondence
} 
alterou os teores de carboidratos solúveis (CHOS) e poder tampão. As silagens de capim-elefante obtidas apresentaram bom padrão fermentativo, com valores de $\mathrm{pH}$ inferior a 3,97 e de $\mathrm{N}_{-} \mathrm{NH}_{3}, 4,07 \%$ do $\mathrm{N}$ total. A inclusão de farelo de arroz proporcionou melhoria no padrão fermentativo das silagens

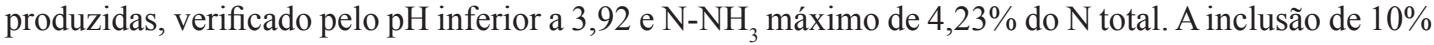
de farelo de arroz na ensilagem do capim-elefante melhorou o valor nutritivo da forragem a ser ensilada e, consequentemente, da silagem produzida.

Palavras-chave: Aditivo. Carboidratos solúveis. Nitrogênio amoniacal. Pennisetum purpureum. pH. Silagem.

\section{Introduction}

Forage availability for ruminants is greatly influenced throughout the year by weather conditions. Silage production is therefore a viable alternative for maintaining animal production by minimizing the effects of seasonal forage production. Among grasses with potential for silage production, elephant grass (Pennisetum purpureum) stands out with production that ranges from 15 to 30 $\mathrm{t}$ of dry matter (DM) ha $\mathrm{hr}^{-1} \mathrm{yr}^{-1}$ In the Midwest region of Brazil, $70 \%$ of the annual production of elephant grass occurs during the rainy season (October to April) (PACIULLO et al., 2008).

Lavezzo (1985) suggested that for silage production, elephant grass should be harvested within 50 to 60 days of its development, when there is a good correlation between plant growth and nutritional value. However, the plant DM content is usually low at this age ( $15 \%$ to $20 \%$ ), which is not recommended for the ensiling process.

Despite the fact that buffering capacity (BC) and water soluble carbohydrate content (WSC) of elephant grass do not limit the ensiling process, Weissbach (1996) reported that a minimum dry matter content is required to avoid undesirable fermentations, which occurs when the ratio between the WSC and BC decreases.

Alternative methods for increasing DM and WSC content of ensiling materials have been widely studied throughout Brazil. Forage wilting, and/ or the inclusion of additives has been successfully used in the production of elephant grass silage (CARVALHO et al., 2007, SILVA et al., 2007).

Of all the additives with potential use in elephant grass ensiling, soybean hulls and rice bran have interesting features such as high DM content.

Soybean (Glycine max (L.) Merr.) hulls are a by-product of grain processing. Approximately $2 \%$ of processed grain results in soybeans hulls which ranges from $0 \%$ to $3 \%$ according to Andrade and Quadros (2011).

Rice bran is derived from the processing of rice, with integuments being removed during the milling process, when the cereal is prepared for human consumption. The bran represents approximately $8 \%$ of the processed rice (LACERDA et al., 2010).

Given that soybean hulls and rice bran are readily available in Mato Grosso state, Brazil, the goal was to evaluate both the chemical composition of silage and the fermentation pattern at ensiling of elephant grass (Pennisetum purpureum Schum. Cv. Roxo) when different quantities of soybean hulls or rice bran were added to the grass.

\section{Materials and Methods}

Trials were conducted at the Experimental Farm of Mato Grosso Federal University in Santo Antônio do Leverger-MT. This is located $141 \mathrm{~m}$ above sea level, at latitude $15^{\circ} 51^{\prime} \mathrm{S}$ and longitude $56^{\circ} 04^{\prime} \mathrm{W}$, at micro-region of Cuiaba (FERREIRA, 2001). The climate, according to the Koppen classification system, is Cwa, indicating it is a tropical, seasonal climate with two well-defined seasons. The region experiences a rainy summer season from October to March, and dry winters (April to September). The average annual rainfall is $1500 \mathrm{~mm}$, with most of the precipitation occurring during December, January and February (FERREIRA, 2001). 
The predominant soil type at the farm consisted of moderate halic plinthisol $\mathrm{Tb}$, with a plateau landscape and medium texture that facilitates water infiltration, soil aeration, root penetration and radicular system development.

Elephant grass was planted with $1.0 \mathrm{~m}$ spacing between grooves. The trial commenced in December 2007, after uniformity cut. Maintenance fertilization was applied at approximately $100 \mathrm{~kg} \mathrm{~N} \mathrm{ha}^{-1}$ and 100 $\mathrm{kg} \mathrm{K}_{2} \mathrm{O} \mathrm{ha}^{-1}$.

The experimental area consisted of 16 rows, each one measuring $30 \mathrm{~m}$ in length, and $1.0 \mathrm{~m}$ apart, covering a total area of $480 \mathrm{~m}^{2}$. A $2.0 \mathrm{~m}$ border was set aside around the entire perimeter of the study plot, reducing the usable area to 14 central rows, each of them with $26 \mathrm{~m}$ length. The total area was reduced to $364 \mathrm{~m}^{2}$.

Two trials were conducted to evaluate additives used in elephant grass ensiling, one with soybean hulls and another with rice bran. The experimental design was completely randomized, with four replicates. Treatments consisted on inclusion of $0 \%$, $5 \%, 10 \%$, and $15 \%$ soybean hull or rice bran additives to unwilted green, chopped elephant grass forage.

Harvesting was conducted 60 days after regrowth, during which the elephant grass had an average height of $1.50 \mathrm{~m}$. All grasses were cut at $10 \mathrm{~cm}$ above ground with the use of a machete. The forage was chopped to approximately 20 $\mathrm{mm}$ in length using a stationary forage cutter. The additives (soybean hulls and rice bran) were manually homogenized to forage mass according to the treatments mentioned above. Chemical analysis (SILVA; QUEIROZ, 2002) of the soybean hulls showed 90.29\% DM, 8.14\% crude protein (CP), $62.99 \%$ neutral detergent fiber (NDF), and 44.61\% acid detergent fiber (ADF), while rice bran with hulls showed 91.14\% DM, 9.05\% CP, 51.28\% NDF, and $30.35 \%$ ADF.

A sample of the chopped forage (500 g) was collected during ensiling, and was placed in paper bags and dried in a forced-air oven at $55^{\circ} \mathrm{C}$ for $72 \mathrm{~h}$.
Pre-dried samples were weighed, and then ground in a Wiley mill until the samples could pass through a 20 mesh steel sieve. Each of these samples was stored in polyethylene containers for analysis of DM (SILVA; QUEIROZ, 2002) and WSC (SILVEIRA, 1975). A second sample (500 g) was frozen in plastic bags for $\mathrm{BC}$ determination following the method described by Playne and McDonald (1966).

Each experimental silo (plot) consisted of a PVC pipe of $10 \mathrm{~cm}$ diameter and $50 \mathrm{~cm}$ length, with the capacity to condition $2.50 \mathrm{~kg}$ of forage (density of $600 \mathrm{~kg}$ of green forage $\mathrm{m}^{-3}$ ). Timber sockets were used to compress the matter inside the silos. These were sealed with PVC caps with Bunsen valves that allowed fermentation gases to escape. Then, the caps were sealed with tape.

Silos were opened 40 days after ensiling. The upper and lower $5 \mathrm{~cm}$ portions of matter inside the silos were discarded. The remaining silage was divided into two portions. The first (500 g) was transferred to plastic bags and frozen to measure $\mathrm{pH}$, in accordance with Silva and Queiroz (2002) and ammonia nitrogen content $\left(\mathrm{N}-\mathrm{NH}_{3}\right)$, according to Tosi (1973). The second part (500g) was placed in paper bags and dried for $72 \mathrm{~h}$ in a forced-air oven at $55^{\circ} \mathrm{C}$. Pre-dried samples were weighed, ground in a Wiley mill until they could pass through a 20 mesh steel sieve, and stored in polyethylene containers for chemical analysis.

The DM and CP contents were determined according to methods described by Silva and Queiroz (2002). Levels of NDF and ADF were determined according to methods by Van Soest et al. (1991), using tissue non-tissue bags (TNT$100 \mathrm{~g} \mathrm{~m}^{-2}$ ). Indigestible NDF (iNDF) content was determined using methods described by Cochran et al. (1986).

The total digestible nutrient content (TDN) was estimated according to the following formula by Undersander et al. (1993):

$\mathrm{TDN}(\% \mathrm{DM})=88.9-[\mathrm{ADF}(\% \mathrm{DM}) \times 0.779]$.

All data were analyzed by analysis of variance 
and regression, using SAEG, version 9.1 (RIBEIRO

JÚNIOR; MELO, 2008) software. Probabilities less than $5 \%$ were considered statistically significant.

\section{Results and Discussion}

The chemical composition of elephant grass forage with soybean hulls or rice bran is shown in Table 1.

Table 1. Average content of dry matter (DM), crude protein (CP), neutral detergent fiber (NDF), acid detergent fiber (ADF), total digestible nutrients (TDN), water soluble carbohydrates (WSC), buffering capacity (BC) and in vitro dry matter digestibility (IVDMD) of elephant grass forage with soybean hulls or rice bran added to it.

\begin{tabular}{|c|c|c|c|c|c|c|c|}
\hline \multirow{2}{*}{ Variables } & \multicolumn{4}{|c|}{ Additive level (\%) } & \multirow{2}{*}{ Regression equation $^{1}$} & \multirow{2}{*}{$\mathrm{R}^{2}$} & \multirow{2}{*}{$\begin{array}{l}\text { CV } \\
(\%)\end{array}$} \\
\hline & 0 & 5 & 10 & 15 & & & \\
\hline \multicolumn{8}{|c|}{ Soybean hulls } \\
\hline $\mathrm{DM}(\%)$ & 17.87 & 26.92 & 31.62 & 26.18 & $\hat{Y}=17.7278+2.5022 X^{* *}-0.1152 X^{2^{* *}}$ & 0.99 & 8.15 \\
\hline $\mathrm{CP}(\% \mathrm{DM})$ & 5.16 & 7.42 & 7.83 & 8.18 & $\hat{\mathrm{Y}}=5.2509+0.4766 \mathrm{X}^{* *}-0.01914 \mathrm{X}^{2 * *}$ & 0.97 & 6.01 \\
\hline NDF (\% DM) & 68.35 & 67.3 & 66.15 & 66.08 & $\hat{Y}=68.1661-0.15915 X^{*}$ & 0.91 & 1.85 \\
\hline $\operatorname{ADF}(\% \mathrm{DM})$ & 40.4 & 42.91 & 43.29 & 43.98 & $\hat{Y}=40.5273+0.4941 X^{* *}-0.0181 X^{2^{*}}$ & 0.96 & 1.67 \\
\hline TDN (\% DM) & 59.59 & 57.08 & 56.7 & 56.01 & $\hat{\mathrm{Y}}=59.427-0.4941 \mathrm{X}^{* *}+0.0181 \mathrm{X}^{2^{*}}$ & 0.96 & 1.24 \\
\hline WSC (\% DM) & 14.03 & 13.94 & 15.2 & 13.59 & $\overline{\mathrm{y}}=14.19$ & - & 6.45 \\
\hline $\mathrm{BC}^{2}$ & 8.41 & 9.43 & 8.99 & 9.93 & $\overline{\mathrm{y}}=9.19$ & - & 13.21 \\
\hline $\operatorname{IVDMD}(\% \mathrm{DM})$ & 59.72 & 72.59 & 70.7 & 81.16 & $\hat{Y}=59.7236+1.249 X^{* *}$ & 0.84 & 20.83 \\
\hline \multicolumn{8}{|c|}{ Rice bran } \\
\hline $\mathrm{DM}(\%)$ & 17.87 & 28.42 & 28.89 & 32.39 & $\hat{Y}=20.2912+0.8805 X^{*}$ & 0.82 & 13.75 \\
\hline $\mathrm{CP}(\% \mathrm{DM})$ & 5.16 & 7.35 & 7.12 & 7.36 & $\hat{Y}=5.305+0.422 X^{* *}-0.0196 X^{2^{*}}$ & 0.99 & 10.07 \\
\hline NDF (\% DM) & 68.35 & 64.84 & 61.46 & 61.4 & $\hat{Y}=68.5124-1.0014 X^{* *}+0.0344 X^{2^{*}}$ & 0.98 & 2.09 \\
\hline $\operatorname{ADF}(\% \mathrm{DM})$ & 40.4 & 39.19 & 37.23 & 37.45 & $\hat{\mathrm{Y}}=40.195-0.2161 \mathrm{X}^{* *}$ & 0.86 & 3.66 \\
\hline TDN (\% DM) & 59.59 & 60.8 & 62.76 & 62.54 & $\hat{\mathrm{Y}}=59.805+0.216 \mathrm{X}^{* *}$ & 0.86 & 2.3 \\
\hline WSC (\% DM) & 14.03 & 13.85 & 15.55 & 16.41 & $\hat{\mathrm{Y}}=13.6396+0.17709 \mathrm{X}^{*}$ & 0.86 & 3.82 \\
\hline $\mathrm{BC}^{2}$ & 8.41 & 8.24 & 7.22 & 11.98 & $\hat{Y}=8.7469-0.5453 X+0.0492 X^{2^{*}}$ & 0.83 & 23.29 \\
\hline IVDMD (\% DM) & 59.72 & 59.47 & 50.69 & 54.08 & $\overline{\mathrm{y}}=55.99$ & - & 34.26 \\
\hline
\end{tabular}

$1 * * ; *$ : Significant at probability levels of $1 \%$ and $5 \%$ for F-test. ${ }^{2}$ : eq.mg $\mathrm{HCl} 100 \mathrm{~g}^{-1} \mathrm{DM}$.

A quadratic effect $(\mathrm{P}<0.05)$ of soybean hull levels was observed on DM content of elephant grass forage before ensiling, with a maximum estimated value of $31.31 \%$ when using $10.86 \%$ of soybean hulls. Muck (1988) reported that an ideal fermentation inside the silo is expected when the forage to be ensiled has a DM content between $28 \%$ and $35 \%$. The addition of $10.86 \%$ of soybean hull therefore promoted the appropriate DM content in the forage to obtain good silage.

With regard to the DM content of forage prior to ensiling, there was a significant increase of $0.88 \%$ in the DM content for every $1 \%$ of rice bran added $(\mathrm{P}<0.05)$. The addition of rice bran also enhanced the nutritive value of ensiled forage (Table 1). The addition of $8.75 \%$ of rice bran to elephant grass during ensiling resulted in a forage DM content of $28 \%$, which is the minimum required to obtain good silage according to Muck (1988). Additives such as these reduce DM losses, limit secondary fermentation, improve aerobic stability and increase the nutritional value of silage (HENDERSON, 1993). Ribeiro et al. (2009) reported that the use of citrus pulp and soybean hulls on marandu palisade grass silage (Brachiaria brizantha cv. BRS Marandu), resulted in an increase in the DM content of the forage, in which the high DM content additives were included.

There was no significant increase $(\mathrm{P}>0.05)$ in WSC content or $\mathrm{BC}$ of elephant grass forage due 
to the addition of soybean hull. The mean values were $14.19 \%$ and 9.19 eq.mg $\mathrm{HCl} 100 \mathrm{~g}^{-1} \mathrm{DM}$, respectively. In contrast, the addition of rice bran to chopped elephant grass resulted in a significant linear increase $(\mathrm{P}<0.05)$ in the WSC content of material, with a $0.177 \%$ increase for every $1 \%$ of rice bran added (Table 1). The WSC content is considered an indicator of the quality of the forage to be used for ensiling, with a minimum concentration of 2.5 to $3.0 \%$ required (HAIGH, 1990). Despite some elephant grass cultivars possessing a WSC content greater than 16\% of DM (Taiwan A-148), reasonable silages have been produced when the cultivar used has a WSC content below 13\% to $15 \%$. This was according to Machado Filho and Muhlbach (1986).

The addition of $10 \%$ rice bran to elephant grass forage increased the DM content by $29 \%$ and WSC by $15.41 \%$. Zanine et al. (2010) tested the effects of cassava scrapings on elephant grass ensiling and reported an increase on DM and WSC content in the forage with additive inclusion, similar to the rice bran at this work.

A quadratic response $(\mathrm{P}<0.05)$ to rice bran levels on forage $\mathrm{BC}$ was observed. The addition $8.99 \%$ of rice bran resulted in the lower $\mathrm{BC}$ value of 7.17 eq.mg $\mathrm{HCl} 100 \mathrm{~g}^{-1} \mathrm{DM}$. Adding more rice bran increased the $\mathrm{BC}$, which was possibly due to the higher crude protein content of rice bran, which can act as a buffering agent in the forage (JOBIM et al., 2007). Elephant grass forage BC, with or without the addition of soybean hulls or rice bran, was always lower than 15 eq.mg $\mathrm{HCl} 100 \mathrm{~g}^{-1} \mathrm{DM}$ (FERRARI JUNIOR; LAVEZZO, 2001). Lavezzo (1985) reported that the ideal fermentation can be achieved when the forage to be ensiled has a DM content ranging between $28 \%$ and $34 \%$. Under these conditions, a WSC content of $6 \%$ to $8 \%$ would be sufficient to allow lactic fermentation. This is provided when $\mathrm{BC}$ is not high.

There was a linear effect $(\mathrm{P}<0.05)$ of soybean hull levels on forage NDF. For every $1 \%$ of soybean hull added to chopped elephant grass forage there was $0.15 \%$ decrease in NDF content (Table 1 ). A quadratic effect $(\mathrm{P}<0.05)$ due to soybean hull levels on forage ADF content was also observed, with a maximum estimated value of $43.89 \%$ when using $13.65 \%$ of soybean hulls. The opposite occurred to the TDN content in forage in which soybean hulls were added. There was a significant quadratic effect $(\mathrm{P}<0.05)$ due to soybean hull levels on the CP content of forage (Table 1). The maximum estimated value of $8.21 \% \mathrm{CP}$ was achieved when $12.45 \%$ of soybean hulls was added. These results are due to the chemical composition of soybean hulls.

A quadratic effect $(\mathrm{P}<0.05)$ due to rice bran levels on forage NDF (Table 1) was also observed. A minimum estimated value of $61.22 \%$ of NDF occurred following the inclusion of $14.55 \%$ rice bran. These decreases may have been due to the lower NDF content of rice bran (31.28\%) compared to the elephant grass $(68.51 \%)$. Rice bran exerted a linear effect on forage ADF levels $(\mathrm{P}<0.05)$, resulting in a decrease of $0.21 \%$ for every $1 \%$ of rice bran added to elephant grass forage prior to ensiling (Table 1). A quadratic effect due to rice bran levels on forage CP content was similarly observed. The addition of up to $10.76 \%$ of rice bran induced an increase in elephant grass forage CP content of $7.57 \%$. This was due to the higher $\mathrm{CP}$ content in rice bran $(9.05 \%)$.

The results of the chemical composition and fermentation characteristics of elephant grass silage with soybean hulls and rice bran are shown in Table 2 . 
Table 2. Average content of dry matter (DM), crude protein (CP), neutral detergent fiber (NDF), acid detergent fiber (ADF), total digestible nutrients (TDN), water soluble carbohydrates (WSC), ammonia nitrogen (AN), $\mathrm{pH}$ and in vitro dry matter digestibility (IVDMD) of elephant grass silage with soybean hulls or rice bran added to it.

\begin{tabular}{|c|c|c|c|c|c|c|c|}
\hline \multirow{2}{*}{ Variables } & \multicolumn{4}{|c|}{ Additive level (\%) } & \multirow{2}{*}{ Regression equation $^{1}$} & \multirow{2}{*}{$\mathrm{R}^{2}$} & \multirow{2}{*}{$\begin{array}{l}\mathrm{CV} \\
(\%)\end{array}$} \\
\hline & 0 & 5 & 10 & 15 & & & \\
\hline \multicolumn{8}{|c|}{ Soybean hulls } \\
\hline $\operatorname{DM}(\%)$ & 23.75 & 29.78 & 29.49 & 32.92 & $\overline{\mathrm{y}}=29.74$ & - & 16.57 \\
\hline $\mathrm{CP}(\% \mathrm{DM})$ & 4.42 & 6.19 & 7.09 & 7.51 & $\hat{Y}=4.44817+0.4064 X^{* *}-0.01356 X^{2^{*}}$ & 0.99 & 9.72 \\
\hline NDF (\% DM) & 65.75 & 61.88 & 61.52 & 62.76 & $\overline{\mathrm{y}}=62.98$ & - & 3.93 \\
\hline $\mathrm{ADF}(\% \mathrm{DM})$ & 41.14 & 39.48 & 41.61 & 42.62 & $\overline{\mathrm{y}}=41.22$ & - & 5.32 \\
\hline TDN (\% DM) & 58.85 & 60.51 & 58.38 & 57.36 & $\overline{\mathrm{y}}=58.78$ & - & 3.73 \\
\hline WSC (\% DM) & 8.67 & 6.27 & 7.13 & 5.17 & $\hat{Y}=8.2643-0.19307 X^{* *}$ & 0.71 & 17 \\
\hline AN $(\%$ total $N)$ & 4.15 & 4.3 & 3.84 & 3.98 & $\overline{\mathrm{y}}=4.07$ & - & 13.31 \\
\hline $\mathrm{pH}$ & 3.92 & 3.95 & 3.93 & 3.97 & $\hat{Y}=3.9297+0.00245 X^{*}$ & 0.55 & 0.63 \\
\hline $\operatorname{IVDMD}(\% \mathrm{DM})$ & 60.83 & 77.96 & 87.73 & 69.57 & $\hat{Y}=60.8396+6.0113 X^{*}-0.3527 X^{2^{* *}}$ & 0.95 & 27.78 \\
\hline \multicolumn{8}{|c|}{ Rice bran } \\
\hline $\operatorname{DM}(\%)$ & 23.75 & 26.52 & 29.86 & 35.03 & $\hat{\mathrm{Y}}=25.322+0.5631 \mathrm{X}^{*}$ & 0.84 & 14.39 \\
\hline $\mathrm{CP}(\% \mathrm{DM})$ & 4.42 & 5.75 & 5.97 & 6.41 & $\hat{Y}=4.4079+0.3704 X^{* *}-0.0176 X^{2^{* *}}$ & 0.99 & 7.93 \\
\hline NDF (\% DM) & 65.75 & 62.39 & 60.86 & 58.4 & $\overline{\mathrm{y}}=59.74$ & - & 14.26 \\
\hline $\mathrm{ADF}(\% \mathrm{DM})$ & 41.14 & 39.03 & 38.08 & 37.13 & $\hat{Y}=40.7998-0.2598 X^{* *}$ & 0.95 & 2.02 \\
\hline TDN (\% DM) & 58.85 & 60.96 & 61.91 & 62.86 & $\hat{\mathrm{Y}}=59.2002+0.259 \mathrm{X}^{* *}$ & 0.95 & 1.28 \\
\hline WSC (\% DM) & 8.67 & 7.94 & 8.91 & 9.03 & $\overline{\mathrm{y}}=8.64$ & - & 15.68 \\
\hline $\mathrm{AN}(\%$ total $\mathrm{N})$ & 4.15 & 4.49 & 3.93 & 4.34 & $\overline{\mathrm{y}}=4.23$ & - & 12.24 \\
\hline $\mathrm{pH}$ & 3.92 & 3.85 & 3.85 & 3.8 & $\hat{Y}=3.9167-0.0079 X^{* *}$ & 0.93 & 0.59 \\
\hline $\operatorname{IVDMD}(\% \mathrm{DM})$ & 60.83 & 54.19 & 51.49 & 49.3 & $\hat{Y}=53.9525-0.309 X^{*}$ & 0.93 & 13.27 \\
\hline
\end{tabular}

$1 * * ; *$ Significant at probability levels of $1 \%$ and $5 \%$ for F-test.

Soybean hulls, when added to elephant grass, linearly reduced $(\mathrm{P}<0.05)$ the silage WSC content, with every $1 \%$ of soybean hull added decreasing it by $0.19 \%$ (Table 2 ). Rice bran also promoted a decrease in WSC content in the silage $(8.64 \%)$ compared to the forage $(14.19 \%)$. The difference in WSC content between silage and forage suggests that this fraction was consumed during the fermentation process by lactic acid bacteria. Ferrari Junior and Lavezzo (2001) reported a similar increase in consume of WSC contained in elephant grass silage when mixed with cassava meal. Despite the low WSC content in elephant grass forage, the fermentation process provided satisfactory silage with suitable values of $\mathrm{pH}$ and $\mathrm{N}-\mathrm{NH}_{3}$.

With regard to silage DM content, there was a significant increase of $0.56 \%$ for every $1 \%$ of rice bran added $(\mathrm{P}<0.05)$. This indicated that rice bran possesses adequate moisture absorption capacity.
Both soybean hulls and rice bran had an effect on silage $\mathrm{pH}$. There was an estimated increase of 0.002 $\mathrm{pH}$ units for every $1 \%$ of soybean hulls added. A decrease of $0.0079 \mathrm{pH}$ units resulted for every $1 \%$ of rice bran added to elephant grass forage (Table 2). Since good silage has $\mathrm{pH}$ values ranging from 3.8 to 4.2 (MCDONALD et al., 1991), the addition of soybean hulls or rice bran to forage promoted an ideal acidity level.

To assess the efficiency of the fermentation process, $\mathrm{pH}$ levels should not be the only parameters measured. The $\mathrm{N}^{-\mathrm{NH}_{3}}$ content, which is a product of undesirable fermentation by bacteria of the Clostridium genus, should also be considered. The addition of soybean hulls did not significantly ( $\mathrm{P}>$

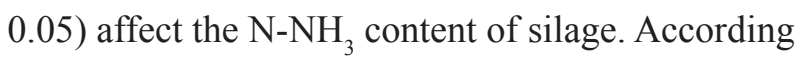
to McDonald et al. (1991), a good silage should contain, a maximum of $11 \%$ of $\mathrm{N}^{-\mathrm{NH}_{3}}$ total $\mathrm{N}^{-1}$. Based on these figures, it is clear that elephant grass 
silages treated with soybean hulls and rice bran presented desirable fermentations.

According to Pahlow et al. (2003), silage with low $\mathrm{pH}$ values inhibited proteolytic bacteria, reducing proteolysis and, consequently, $\mathrm{N}-\mathrm{NH}_{3}$ production. The results suggest that the inclusion of soybean hulls and rice bran increase silage DM content, promoting the development of lactic acid bacteria over enterobacteria and Clostridium, which results in lower $\mathrm{pH}$ and $\mathrm{N}-\mathrm{NH}_{3}$ levels in the silages.

The forages used in this study, both additivated and control treatments, were generally well conserved, presenting good fermentation profiles, with ideal $\mathrm{pH}$ and $\mathrm{N}-\mathrm{NH}_{3}$ values, as according to McDonald et al. (1991). It should be noted, however, that silage without any additives, produced unpleasant odors, which are characteristic of undesirable fermentations. They also presented mould and were, therefore, considered unfit for animal consumption.

There was a quadratic effect $(\mathrm{P}<0.05)$ due to the addition of soybean hull levels on silage CP content (Table 2). This resulted in a maximum estimated value of $7.49 \% \mathrm{CP}$ content when $14.98 \%$ of soybean hulls were added. This suggests a little loss of CP, which can be attributed to the possible reduction by proteolytic microorganisms. This was in addition to heterofermentative bacteria, which develop at the beginning of the fermentation process, when the decrease in $\mathrm{pH}$ is less pronounced. High moisture content and low soluble carbohydrate concentration can also be considered conditioning factors for the development of the afore-mentioned microorganism (PAHLOW et al., 2003). The low CP content observed in silages without additive was likely due to the loss of soluble nitrogen compounds in the effluent. According to Pinho et al. (2008), grass ensiling without additives is subject to significant losses by effluent, which can contain large amounts of organic compounds, including proteins. For silages with increasing levels of soybean hulls compared to the forages, the decrease in CP content can be attributed to the dilution effect, as a result of additive DM proportion.

A quadratic effect $(\mathrm{P}<0.05)$ due to rice bran levels on silage CP content was observed, with a maximum value of $6.36 \% \mathrm{CP}$ resulting from the addition of $10.53 \%$ of rice bran to elephant grass forage. This was possibly due to the higher $\mathrm{CP}$ content in rice bran (9.05\%). The levels observed in this study were similar to those reported by Rodrigues et al. (2005), who added citrus pulp with $6.79 \%$ CP to forage. They showed that a higher CP content was achieved when the forage was treated with $7.61 \%$ of the additive.

The reduction in silage NDF content (62.98\%), when compared to ensiled forage with added soybean hulls is interesting, since the ruminant intake is usually limited by NDF content ranging from 1.0 to $1.4 \%$ of body weight (MERTENS, 1987). The decrease of NDF on diets containing a high proportion of roughage may contribute to an increase in DM intake, with incremental increase in energy on the ruminant diet (JUNG; ALLEN, 1995).

A linear effect $(\mathrm{P}<0.05)$ due to the addition of rice bran was observed on silage ADF content. A decrease in $\mathrm{ADF}$ content occurred following an increase in rice bran levels, with an estimated reduction of $0.25 \%$ on silage for every $1 \%$ of rice bran added to elephant grass forage prior to ensiling (Table 2). The linear reduction in ADF content of silage may have been due to a direct response to lower levels of ADF in rice bran (30.35\%) compared to elephant grass forage at ensiling $(40.19 \%)$. Zanine et al. (2010) tested the effects of adding cassava scrapings to elephant grass ensiling and observed a similar response.

There was an increase of $0.22 \%$ and $0.26 \%$ TDN in the forage (Table 1) and silage of elephant grass, respectively, (Table 2) for every $1 \%$ of rice bran added to the forage. The increase in energy following rice bran inclusion was due to its chemical composition. There was an increase in $\mathrm{CP}$ and WSC, with a concomitant decrease in NDF and 
ADF that correlated with energy increments (Table 2 ). The addition of $15 \%$ of rice bran to chopped elephant grass forage provided silage with $62.86 \%$ TDN. This was similar to levels reported by Pereira et al. (2008) for corn silage (63.7\% NDT), which is considered the standard silage.

For soybean hulls, ADF and TDN levels of $41.21 \%$ and $58.78 \%$, respectively were observed. These results were also reported by Bernardino et al. (2005), who evaluated the addition of coffee hulls at levels of $0 \%, 10 \%, 20 \%, 30 \%$, and $40 \%$ on elephant grass forage with $12.4 \%$ of DM content. They showed that silage ADF levels were not affected by the addition of coffee hulls, which was due to similar ADF content between ensiled elephant grass and the additive.

\section{Conclusions}

It is therefore concluded that the inclusion of $10 \%$ of soybean hulls increased the dry matter content of elephant grass forage $(31 \%)$, but did not alter the water soluble carbohydrates content or the buffering capacity. The addition of rice bran increased the content of dry matter and water soluble carbohydrate of the elephant grass forage for ensiling, improving the fermentation pattern of produced silages, resulting in ideal values of $\mathrm{pH}$ and ammonia nitrogen. The inclusion of $10 \%$ of rice bran on elephant grass ensiling eliminated the need for wilting and also improved the nutritional value of the silage. The elephant grass silage produced in the present study exhibited good fermentation, with ideal $\mathrm{pH}$ and ammonia nitrogen values.

\section{References}

ANDRADE, A. P.; QUADROS, D. G. Composição bromatológica da casca de soja amonizada com uréia. Revista de Biologia e Ciências da Terra, João Pessoa, v. 11, n. 1, p. 38-46, 2011.

BERNARDINO, F. S.; GARCIA, R.; ROCHA, F. C.; SOUZA, A. D.; PEREIRA, O. G. Produção e características do efluente e composição bromatológica da silagem de capim-elefante contendo diferentes níveis de casca de café. Revista Brasileira de Zootecnia, Viçosa, MG, v. 34, n. 6, p. 2185-2291, 2005.

CARVALHO, G. G. P.; GARCIA, R.; PIRES, A. J. V.; PEREIRA, O. G.; AZEVEDO, J. A. G.; CARVALHO, J. C. Valor nutritivo de silagens de capim-elefante emurchecido ou com adição de farelo de cacau. Revista Brasileira de Zootecnia, Viçosa, MG, v. 36, n. 5, p. 1495 1501, 2007.

COCHRAN, R. C.; ADAMS, D. C.; WALLACE, J. D.; GALYEAN, M. L. Predicting digestibility of different diets with internal markers: evaluation of four potential markers. Journal of Animal Science, Champaign, v. 63, n. 5, p. 1476-1483, 1986.

FERRARI JUNIOR, E.; LAVEZZO, W. Qualidade da silagem de capim-elefante (Pennisetum purpureum Schum.) emurchecimento ou acrescido de farelo de mandioca. Revista Brasileira de Zootecnia, Viçosa, MG, v. 30, n. 5, p. 1424-1431, 2001.

FERREIRA, J. C. U. Mato Grosso e seus municipios. Cuiabá: Secretaria do Estado de Educação, 2001. 660 p.

HAIGH, P. M. Effect of herbage water-soluble carbohydrate content and weather conditions at ensilage on the fermentation of grass sileges made on commercial farms. Grass and Forage Science, Oxford, v. 45, n. 3, p. 263-271, 1990.

HENDERSON, N. Silage additives. Animal Feed Science, Amsterdan, v. 45, n. 1, p. 35-56, 1993.

JOBIM, C. C.; NUSSIO, L. G.; REIS, R. A.; SCHMIDT, P. Avanços metodológicos na avaliação da qualidade da forragem conservada. Revista Brasileira de Zootecnia, Viçosa, MG, v. 36, n. 1, p. 101-119, 2007.

JUNG, H. G.; ALLEN, M. S. Characteristics of plant cell walls affecting intake and digestibility of forages by ruminants. Journal of Animal Science, Champaing, v. 73, n. 9, p. 2774-2790, 1995.

LACERDA, D. B. C. L.; SOARES JÚNIOR, M. S. S.; BASSINELLO, P. Z.; CASTRO, M. V. L. de; SILVALOBO, V. L.; CAMPOS, M. R. H.; SANTOS SIQUEIRA, B. dos. Qualidade de farelos de arroz cru, extrusado e parboilizado. Pesquisa Agropecuária Tropical, Goiânia, v. 40, n. 4, p. 521-530, 2010.

LAVEZZO, W. Silagem de capim-elefante. Informe Agropecuário, Belo Horizonte, v. 11, n. 132, p. 50-57, 1985.

MACHADO FILHO, L. C. D.; MÜHLBACH, P. R. F. Efeito do emurchecimento na qualidade das silagens de capim-elefante cv. Cameroun (P. purpureum Schum.) e de milheto ( $P$. americanum (L.) Leeke), avaliadas 
quimicamente. Revista Brasileira de Zootecnia, Viçosa, MG, v. 15, n. 3, p. 224-233, 1986.

McDONALD, P. J.; HENDERSON, A. A. R.; HERON, S. J. E. The biochemistry of silage. 2. ed. Marlow, Bucks, UK. Chalcombe Publications, 1991. 340 p.

MERTENS, D. R. Predicting intake and digestibility using mathematical models of ruminal function. Journal of Dairy Science, Madison, v. 64, n. 5, p. 1548-1558, 1987.

MUCK, R. E. Factors influencing silage quality and their implications for management. Journal of Dairy Science, Madison, v. 71, n. 11, p. 2992-3002, 1988.

PACIULLO, D. S.; DERESZ, F.; LOPES, F. C.; AROEIRA, L. J.; VERNEQUE, R. S. Disponibilidade de matéria seca, composição química e consumo de forragem em pastagem de capim-elefante nas estações do ano. Arquivo Brasileiro de Medicina Veterinária e Zootecnia, Belo Horizonte, v. 60, n. 4, p. 904-910, 2008.

PAHLOW, G.; MUCK, R. E.; DRIEHUIS, F.; ELFERINK, S. J.; SPOELSTRA, S. F. Microbiology of ensiling. In: SILAGE SCIENCE AND TECHNOLOGY, 42., 2003, Madison. Proceedings... Madison: ASCSSASSSA, 2003. p. 31-93.

PEREIRA, M. S.; RIBEIRO, E. L. A.; MIZUBUTI, I. Y.; ROCHA, M. A.; KURAOKA, J. T.; NAKAGHI, E. Y. O. Consumo de nutrientes e desempenho de cordeiros em confinamento alimentados com dietas com polpa cítrica úmida prensada em substituição a silagem de milho. Revista Brasileira de Zootecnia, Viçosa, MG, v. 37, n. 1, p. 134-139, 2008.

PINHO, B. D.; PIRES, A. J. V.; RIBEIRO, L. S. O.; CARVAlHO, G. G. P. Ensilagem de capim-elefante com farelo de mandioca. Revista Brasileira de Saúde e Produção Animal, Salvador, v. 9, n. 4, p. 641-645, 2008.

PLAYNE, M. J.; McDONALD, P. The buffering constituents of herbage and of silage. Journal of the Science of Food and Agricultural, London, v. 17, n. 6, p. 262-268, 1966.

RIBEIRO JÚNIOR, J. I.; MELO, A. L. P. Guia prático para utilização do SAEG. Viçosa, MG: Folha Artes Gráficas Ltda, 2008. 288 p.

RIBEIRO, J. L.; NUSSIO, L. G.; MOURÃO, G. B.; QUEIROZ, O. C. M.; SANTOS, M. C.; SCHIMIDT, P. Efeitos de absorventes de umidade e de aditivos químicos e microbianos sobre o valor nutritivo, o perfil fermentativo e as perdas em silagens de capim-marandu. Revista Brasileira de Zootecnia, Viçosa, MG, v. 38, n. 2, p. 230-239, 2009.
RODRIGUES, P. H. M.; BORGATTI, L. M. O.; GOMES, R. W.; PASSINI, R.; MEYER, P. M. Efeito da adição de níveis crescentes de polpa cítrica sobre a qualidade fermentativa e o valor nutritivo da silagem de capimelefante. Revista Brasileira de Zootecnia, Viçosa, MG, v. 34, n. 4, p. 1138-1145, 2005.

SILVA, D. J.; QUEIROZ, A. C. Análise de alimentos: métodos químicos e biológicos. 3. ed. Viçosa, MG: Universidade Federal de Viçosa, MG, 2002. 235 p.

SILVA, F. F.; AGUIAR, M. S. M. A.; VELOSO, C. M.; PIRES, A. J. V.; BONOMO, P.; DUTRA, G. S.; ALMEIDA, V. S.; CARVALHO, G. G. P.; SILVA, R. R.; DIAS, A. M.; ÍTAVO, L. C. V. Bagaço de mandioca na ensilagem do capim-elefante: qualidade das silagens e digestibilidade dos nutrientes. Arquivo Brasileiro de Medicina Veterinária e Zootecnia, Belo Horizonte, v. 59, n. 3, p. 719-729, 2007.

SILVEIRA, A. C. Técnicas para produção de silagens In: SIMPÓSIO SOBRE MANEJO DA PASTAGEM, 2., 1975, Piracicaba. Anais... Piracicaba: ESALQ, 1975. p. 156-186.

TOSI, H. Ensilagem de gramíneas tropicais sob diferentes tratamentos. 1973. Tese (Doutorado em Zootecnia) Faculdade de Ciências Médicas e Biológicas de Botucatu, Botucatu.

UNDERSANDER, D.; MERTENS, D. R.; THIEX, N. Forage analysis procedures. Omaha: National Forage Testing Associaton, 1993. $154 \mathrm{p}$.

VAN SOEST, P. J.; ROBERTSON, J. B.; LEWIS, B. A. Methods for dietary fiber, neutral detergent fiber, and nonstarch polyssacarides in relation to animal nutrition. Journal of Dairy Science, Madison, v. 74, n. 10, p. 35833597, 1991.

WEISSBACH, F. New developments in crop conservation. In: INTERNATIONAL SILAGE CONFERENCE, 11., 1996, Aberystwyth. Proceedings... Aberystwyth: Institute of Grassland and Environmental Research, 1996. p. 11-25.

ZANINE, A. D. M.; SANTOS, E. M.; DÓREA, J. R. R.; DANTAS, P. A. D. S.; SILVA, T. C. D.; PEREIRA, O. G. Evaluation of elephant grass silage with the addition of cassava scrapings. Revista Brasileira de Zootecnia, Viçosa, MG, v. 39, n. 12, p. 2611-2616, 2010. 
